\title{
The Importance of the Environment in Learning Indonesian Language
}

\author{
Oleh : Afifah Tu Sahada \\ afifahtshd24@gmail.com
}

Environmental problems are nothing new. Environmental problems such as forest burning, environmental pollution, hunting of protected animals and plants are problems that have existed in the past, and continue without any resolution. These environmental problems are caused by careless and intensive human activities in natural areas to improve their quality of life. Environmental damage causes a series of problems with natural resources, climate, pollution, food, and the economy, resulting in an imbalance in the environment. One of the efforts to solve this sustainable environmental problem is to instill in the young generation the importance of protecting the environment from an early age. Small things such as not littering, using water as needed, and so on are the first steps that can be done. Instilling a sense of responsibility and awareness of protecting the environment can be done in schools by applying environmental materials in learning. One of the lessons that can be related to environmental material is language learning.

According to Uyar and Ensar (in Ramadhan et al, 2019), using environmental themes in text learning can trigger student interest in learning language and this can have implications for increasing students' knowledge of the environment. Environmental based learning aims to make students participate in protecting the environment. Not seeing the environment as something that can be exploited for personal gain, but as a valuable asset that deserves to be protected for human survival. Therefore, it is important to develop knowledge about the environment, environmental awareness and changes in behavior towards the environment. Environmental education can help students rethink the relationship between humans and the environment, understand the environment, be aware of environmental problems and consider environmental problems related to life (Ramadhan et al, 2019).

According to Obasoro, Oyinloye, and Ilensami (in Ramadhan et al, 2019), students need to have experience in taking initiatives with respect to urgent requirements. in the area of global and societal challenges. In line with that, according to Bergman B, G (in Ramadhan et al, 2019), teachers play an important role in teaching environmental education. The teacher can provide environmental material to students so that students can understand the right 
examples that can be found around them. Apart from teachers, students also have an important role in the learning process. Because without a response or action to apply the material provided by the teacher, the purpose of this learning will not be achieved.

Based on the problems described above, the authors conducted research on the importance of the environment in Indonesian language learning. The research was conducted by making 10 statements in the form of a google questionnaire. The results obtained from this study are as follows. There were 34 people who answered the questions, $82.4 \%$ women, $17.6 \%$ men. Of the 34 people, 26 people were from Padang State University, 3 people from the Muhammadiyah Bukittinggi University, 2 people from the Riau Islamic University, 1 from STKIP Bukittinggi, 2 students.

The first question, in learning Indonesian, environmental material is very important to learn, 58.8\% answered strongly agree, 41.2\% answered agree, 0\% answered strongly disagree, $0 \%$ answered disagree. The second question, the environment is a factor that affects education in schools, 61.8\% answered agree, 38.2\% answered strongly agree, $0 \%$ answered strongly disagree, $0 \%$ answered disagree. The third question, the atmosphere in the school environment must be created optimally to support students to feel comfortable and comfortable learning, $73.5 \%$ answered strongly agree, $26.5 \%$ answered agree, $0 \%$ answered strongly disagree, $0 \%$ answered disagree. The fourth question, environmental material in Indonesian language learning is related to the use of Indonesian in everyday life, 61.8\% answered agree, 29.4\% answered strongly agree, $8.8 \%$ answered disagree. $0 \%$ answered strongly disagree.

In the fifth question, the advantage of having environmental material in Indonesian language learning is that students can respect and protect the environment well, $61.8 \%$ answered strongly agree, 38.2\% answered agree, $0 \%$ answered strongly disagree, $0 \%$ answered disagree. The sixth question, environmental material can make it easier for students to understand Indonesian language material, 70.6\% answered agree, 26.5 answered strongly agreed, 2.9\% answered disagree, $0 \%$ answered strongly disagreed. The seventh question, the environment can develop students' imagination in learning Indonesian, 69.7\% answered agree, 30.3\% answered strongly agree, $0 \%$ answered strongly disagreed, $0 \%$ answered disagree. The eighth question, the advantage of having environmental material in Indonesian language learning is that students can respect and protect the environment well, 52.9\% answered strongly agree, $47.1 \%$ answered agree, $0 \%$ answered strongly disagreed, $0 \%$ answered disagree. Furthermore, 
the ninth question, the environment can be used as a discussion in Indonesian language learning, $64.7 \%$ answered agree, 36.3\% answered strongly agree, $0 \%$ answered strongly disagreed, $0 \%$ answered disagree. The last question, namely learning can be used as a theme in Indonesian language learning, 58.8 answered agree, 38.2\% answered strongly agreed, 3\% answered disagree, $0 \%$ answered strongly disagreed.

From the results of the author's research above, it can be concluded that environmental material is very important to be applied in Indonesian language learning. Environmental materials make it easier for students to understand Indonesian material well, add to students 'insight, and can build students' ecological intelligence. Environmental material is material that is closely related to everyday life. Therefore, with environmental material the teacher can easily find relevant examples that make students better understand the material provided, so that it can help teachers imply Indonesian language material.

In (Ramadhan, et al (2019)), a person has the same obligation to protect the environment. To be able to protect the environment requires understanding and knowledge of the environment. The teacher plays an important role in conveying this knowledge to students, because students are the next generation who are tasked with protecting the environment. Environmental education can be integrated into other subjects, one of which is language learning. Integration can be done by using the theme of the environment in text learning. Through the text being studied, students can learn the language and gain environmental knowledge through the content of the text that is read. Based on this, it is important for teachers to have environmental knowledge and environmental care attitudes. If the teacher does not have the knowledge and attitude, language learning becomes less meaningful. Teachers must be able to design language learning by integrating various topics, one of which is environmental education. You can use text related to the environment or use an appropriate learning method. This research can be used as an evaluation material for all parties, especially prospective language teachers to increase their knowledge about environmental education. By increasing this knowledge, it can foster an environmental care attitude and can improve skills in integrating the environment. 


\section{REFERENCE}

Bergman B G 2016 Assessing impacts of locally designed environmental education projects on students' environmental attitudes, awareness, and intention to act Environmental Education Reseach22 (4) 480-503.

Buldur, A. and Ömeroglu, E. (2018). An examination of the relationship between pre- school children's and their teacher' attitute and awareness towards the environment Journal of Education and Learning 7(2) 221-9.

Hauchild S, Poltavthenko E and Stoller F L 2012 Going green: Menging environmental education and language instruction English Teaching Forum Number 2 2-13.

Jacobs G M and Cates K.(2012). Global education in second language and teaching. International Journal of Physica 1 and Social Sciences 2 1-22.

Mbete, A. M. (2015). Pembelajaran Bahasa Berbasis Lingkungan: Perspektif Ekolinguitik. RETORIKA: Jurnal Ilmu Bahasa, 1(2),352-364.

Munawaroh, S. 2014. "Pengaruh Lingkungan Sekolah Terhadap Siswa Dalam Pembelajaran Bahasa Indonesia Kelas X Madrasah Aliyah (MA) Daarul Falahiyyah Kampung Panggang, Kecamatan Cisoka, Kabupaten Tanggerang”. Fakultas Ilmu Tarbiyah dan Pendidikan. UIN Jakarta: Jakarta

Obasoro C B, Oyinloye O A and Ilensami A A 2013 The importance of environmental education to secondary education level in Akure South local goverment area, Ondo State Nigeria African Research Review7 (4) 298-306.

Ramadhan, S., Sukma, E., \& Indriyani, V. (2019). Environmental education and disaster mitigation through language learning. IOP Conference Series: Earth and Environmental Science, 314, pp. 1-9.

Tulalessy, Q. D. (2016). Pembelajaran Bahasa Berbasis Lingkungan Sebagai Upaya Membangun Kecerdasan Ekologis. Jurnal Triton Pendidikan, 1(1), 51-56.

Uyar Y and Ensar F 2016 Does mother tongue education support development of environmental literacy in Turkey? An analysis of Turkish course book International Journal of Environmental \& Science Education 11(1) 1-8 